\title{
Demotivation Factors in Using English as Daily Communication in EFL School: Case Study of EFL Learners
}

\author{
Hizbul Wathoni ${ }^{1}$, Ari Safar Wadi ${ }^{2}$, Hanofi Harianto ${ }^{3}$, Ab. Aziz Bin Sulaiman ${ }^{4}$ Selamet \\ Riadi Jaelani*5 \\ Hizbulwathoni96@gmail.com ${ }^{1}$ \\ ari.safarwadi1996@gmail.com ${ }^{2}$ \\ hanofikanjeng@gmail.com ${ }^{3}$ \\ abaziz@unisza.edu.my ${ }^{4}$ \\ selametriadijaelani@yahoo.com ${ }^{5}$ \\ Universiti Sultan Zainal Abidin, Terengganu, Malaysia ${ }^{1,2,3,4}$ \\ Universitas Hamzanwadi, Indonesia ${ }^{5}$
}

Received: November 2021

Accepted: November 2021

Online Published: Desember 2021

\begin{abstract}
This study aimed to describe the causes of students' demotivation in using English for daily communication and find its solutions. The present researcher used the descriptive qualitative method. It was conducted on EFL Learners. There were 15 students to be participants in this study. The data were collected by observing, interviewing, and giving questionnaires to participants about English usage in their Islamic boarding schools. The participants' answers and the video of their daily communication were analyzed by interpreting the handy camera and checking the result of interpretation to the result of questioner and interview. Second, the present researcher compared the result of the handy camera, questioner, and interview to the existing theory to determine the causes of students' demotivation in using English as daily communication and its solution. The result analysis showed that the cause of students' demotivation is their lack of ability to use English, especially in mastering vocabulary and its pronunciation. Other factors were learning contents and materials, teachers, and failure experience. In addition, they prefer to use Arabic because Arabic has been rooted as daily communication in that Islamic boarding school. In comparison, the solution for that problem is that the teachers should pay considerable attention to the students' English ability, especially mastering and pronouncing vocabulary. Also, the teachers are suggested to pay more attention to teaching methods and their behavior to increase students' motivation and interest in second language learning. In addition, the teachers should explicitly make a regulation to divide a period for the student to speak English and Arabic.
\end{abstract}

Keywords: Demotivation factors, English learning Communication, Speaking skill, EFL School

\section{Introduction}

Language is a tool of communication used to express idea, emotion and willingness. Therefore, we should be able to understand how to use language effectively. By using language, the interaction between human can be connected each other. Even language became the most important thing in human's life or it is an absolute need (Freiermuth \& Jarrell, 2006). In this world, there are so many kinds of language. One of the most important languages that need to be mastered is English. As asserted by (Baugh \& Cable, 1993), English language is a language that very important, because it is a way of communication in many countries.

According to (Suparsa et al., 2017), the English language in Indonesia is still considered as one of the most important foreign languages to be learned. Therefore, in Indonesia the 
English language is seen as a first foreign language which is compulsory for student especially in senior high school until university. In learning English there are four skills that should be mastered by the students. English is not only related to the efforts of guiding learners to be able to use English, but also to be skilled in speaking (Irwandi, 2020). Those are listening, speaking, reading, and writing. Among these four skills, speaking skills is considered to be the most important skills that should be taught intensively including in Islamic boarding school.

According to (Clark et al., 2019), speaking skills is important as it is a trait that people need during their life time. We are humans and we cannot live without speaking. Speaking skills can help you in all areas of life. Having the vocabulary and wide range of English skills will assist you in acquiring good job, communicating well to others, in business, at work or school. Also, a good English speaking skills widens your option in job choices such as: sales, business, teaching, management, administration, low, police, government jobs, hospital industry, marketing, customer services and so on. Logically, the teaching process of English language subject should be aimed at preparing EFL students to get a prosperous ability in English specially in speaking skills ability in where they can apply it during they associate with regional or international society.

Contrarily, that process is still difficult to be applied in some schools in Indonesia. Consequently, most of English learner cannot achieve those goals namely a good ability in English specially in speaking skills. It can be caused by many factors. One of the factor is students' low motivation in learning English which is called by demotivation. Asserted by (Çankaya, 2018)demotivation can be described as a decrease or drop in level of motivation. So, demotivation of studying can be defined as a lack motivation to do an activity of studying caused by many factors. It is vary worse condition for the students. It can be the causes of their low achievement in the proses of studying.

Harmoniously, Each learner absolutely ever saturated and bored in doing something, either for work or study. Doing something same everyday make them lazy and want to go out from the work, including studying English every day and using it as daily communication. As what the present researcher found in EFL Learners. It is axiomatic that and English speaking are two most important issues in the process of language learning. Therefore, considering them and conducting researches like the present one about the relationship between them could help language teachers and students to be more efficient in process of language learning and teaching. To put it more clearly, by taking into account these factors, language teachers can be more aware of factors which may encourage language learners to speak and also the factors which may hinder their speaking activities.

Furthermore, the importance of such a study will be more remarkable when we know that tiny or dare to say no study has dealt with the influence of demotivating factors on the speaking ability of language learners in EFL Learners. As a result, conducting this study can shed light on this point by addressing two major questions: 1) what factors that negatively cause 
students' demotivation in speaking English? and how to solve students' demotivation in speaking English?

Based on the argument provided, the present researcher decided to conduct a research entitled “A Study of Students' Demotivation in Using English as Daily Communication in EFL School". It was explained in the article of (Amadi, 2018) entitled Learning the English Passive Voice: Difficulties, learning strategies of Igbo ESL learners and pedagogical implications. It explained that English as a Foreign Language refers to learning and using English as an additional language in a non-English speaking country. Which refer mainly to learning English as a new resident in an English-speaking country?

The difficulty students have with it will depend on what language they already know. Those difficulties are; a) Difficulty in mastering English vocabularies including spelling, idioms and slang also the sheer number of words because English has a usually large varied number of words or English has one of the biggest trickiest vocabularies, b) English grammar is full of subtlety. Its difficulty leads to a great many common mistakes. For example: "Can I have a slice of cake?", "Could I have a slice of cake?" and "May I have a slice of cake?" all express the same idea in differing levels of formality which is even native speakers frequently get errors in it, and c) Pronunciation is difficult and inconsistent. Getting to grips with pronunciation can be a tall order whatever language you are learning.

It is caused by certain sounds in English which are particularly tricky. For example, the distinction between "three" and "tree" can be hard to pronounce. Many EFL learners find the " $t h$ " sound hard to pronounce, because it is comparatively uncommon in other languages. Those who speak languages such as Japanese and most dialects of Chinese find it hard to differentiate between " $\mathrm{r}$ " and " $\mathrm{l}$ " sounds, while the distinction between " $\mathrm{b}$ " and " $\mathrm{v}$ " is problematic for speakers of many other languages, including Spanish and Arabic. These are some difficulties that most of English EFL gets.

(Hartnett, 2016) defines motivation as an important component or factor in the learning process. Learning and motivation have the same importance in order to achieve something. Learning make us gain new knowledge while skills and motivation pushes us or encourage us to go through the learning process. While demotivation means that a lack motivation to do an activity caused by many factors. It is a bad condition for the students which caused low achievement in the proses of their studying. As asserted by (Song \& Kim, 2016), Demotivation can be described as a decrease or drop in level of motivation. Also, it has been discussed in different study that demotivation is a factor that can influence the learners' attitudes towards language learning. So motivation is a fundamental thing that may not absent in every student's self to encourage them as external forcing to achieve the goal of studying.

Four factors that can be dangerous to the learners' motivation, according to (Pitzer \& Skinner, 2017) there are the following: Physical condition which means the atmosphere in the class. For example, if students have to study in the bad lighting classroom, over crowded with too many students, have to look at the small board, or in the unpleasant smell classroom, 
they can lose their motivation or their motivation in learning will be lowered. Method of teaching which refers to the way that students are taught must affect their motivation. Whenever the learners feel bored at the teacher's method, their motivation would likely be lost or gradually decreased. As he said, "If the students loses confidence in the method, they will become demotivated" (Song \& Kim, 2017). The teachers as the most powerful variable of motivation and demotivation can become a major part in demotivating the learners. Success refers to the appropriate level of challenge designed by the teachers. If the difficulty of work and activity is too high or too low, it can lead students to a demotivated situation in learning. As Harmer pointed out, to give high challenge activities may have a negative effect on motivation. Students can also equally be demotivated by too low level of challenge. From (Gong et al., 2019), emotional states such as tiredness, depression, boredom, etc. Obstruct the learning process of the students. Anxiety becomes a factor that influences the affective filter. Low anxiety is more helpful for second language acquisition (Subekti, 2018). This means that learners' anxiety can affect their motivation.

There is one relevant study which is related to this study. It was conducted by (Khouya, 2018). Under the title Analysis on The Differences in EFL Learners 'demotivating Factors after COVID 19 Pandemic. The purpose of this study was to examine the demotivating factors that affect university students' learning English as a foreign language. The participants of the study consist of freshman students majoring in different fields at a state university in Turkey. The students spend eight hours every week in the Foreign Language Centre of the university to improve their English language skills. The main instrument used in the study is a questionnaire prepared by the researcher after an overview of the relevant literature.

The results suggest that, since the students are not required to use English language in their future studies, this long and tedious process of learning a language make them feel tired. Their other courses related to their main fields of study also cause demotivation. The similarities of Khouya's study of the present researcher is the case of study namely students' demotivation. Kind of difference Title of the Study Purpose of the Study Participants of the Study Technique of Data Collection conducted by Khouya study Demotivating Factors in the EFL Environment to examine the demotivating factors that affect to university students' learning English as a foreign language. Freshman students majoring in different fields at a state university in Turkey.

The Questionnaire studying A Study of Students' Demotivation in Using English as Daily Communication in EFL School. To know the causes of students' demotivation and to know how to solve students' demotivation Students in senior high school, especially students of second grader year in senior High School of EFL Learners. According to (Han \& Yin, 2016) asserted that Motivation as an important component or factor in the learning process. Learning and Motivation have the same importance in order to achieve something. Learning make us gain new knowledge and skills while motivation pushes us or encourage us to go through the 
learning process. But lately, motivation is the biggest problem for the student in where they are very lack of it that what we call by demotivation.

It could be the first factor which caused the failure in reaching the goal of their education. Logically, if they have lack spirit to study so that they will not step the good process in searching knowledge, skills professionally, and experiences. Human without motivation is like a tree which never got water and become wilted. So we would say that motivation is the most important thing in education world. Especially in learning English. On the problem above, the present research is very interested to conduct the research to find out the causes of demotivation as well as its solutions.

\section{RESEARCH METHOD}

The researcher used "descriptive qualitative" which means a research methodology is used to investigate indefinite object that cannot be investigated by number (exact sciences. Descriptive qualitative is one of methodologies which discover event, fact, phenomenon, variable and the real situation during the research by providing what exactly occur. This research methodology interprets and describes the relevant data based on the situation which is happening.

Fortunately, this research methodology is appropriate with present researcher's study because this one is focused on a certain phenomenon in the school's environment. In this case, the phenomenon is the activities of students' daily communication in EFL Learners and also teaching and learning English process. The present researcher observed and described the phenomena as clear as possible without manipulation.

Setting of the study refers to place and time to conduct a study. The present researcher conducted the research at EFL Learners from April to Jun for the students of the second graders of EFL Learners.

\subsection{Participants of the Study}

Sampling used in this research is purposive sampling which is a non-probability sample that is selected based on characteristics of a population and the objective of the study. In this case, the subjects of this research are the students in Senior high school, especially students of the second graders of EFL Learners which consist of 15 students.

\subsection{Data Collection}

Instrument is a tool which is used to collect the data. The present researcher used field note to gain the data of observation, smart phone to record and save the result of interview and some questions to note how the students communicate in their daily life.

Technique of Collecting Data

\section{a. Observation}

In this case, the present researcher came to area of the research to observe the learning and teaching process. The present researcher observed the class room, the school condition and students' daily communication. In addition, the present researcher used field note to gain the data of observation 
For additional information or data, the present research gain the data by observing $E F L$ Learners when the students were outside of class room or not in learning and teaching process. While kind of observation is naturalistic observation which is absolutely appropriate in gaining the real information of the participant because this technique involves the researcher to their spontaneous behaviour in natural surroundings.

\section{b. Questionnaire}

To gain more information from the sample, the present researcher provided some questions in form of closed format question that would be answered by the students. In this case, the present researcher used likert questions which was consist of 23 questions.

\section{c. Interview}

The present researcher used semi-structured interview to get the information and data from the sample, specifically to know students' demotivation factor and the solving solution. Semistructured interview is a meeting in which the interviewer does not strictly follow a formalized list of questions. It rather allows for a discussion with the interviewee rather than a straightforward question and answer format. The interviewer prepared only a list of general topics to be addressed, called an interview guide.

To check the trustworthiness of the data, the present researcher used those steps based on the research design stated previously.

First, the present researcher interpreted the handy camera and checked the result of interpretation to the result of questioner and interview. Second, the present researcher compared the result of handy camera, questioner and interview to the exist theory. If the three results of them are same, it can be concluded that the data is valid.

\section{RESULTS AND DISCUSSION}

The result of observation shows the cause of the students' demotivation in using English as daily communication is a strong Arabic environment factor. That thing happens because since this Islamic boarding school exists, it applied Arabic as students' daily communication. Consequently, Arabic has been rooting as students' daily communication from generation to generation and it is difficult to be changed. Besides that, the related observation found three more demotivating factors which prevented students from speaking English: teacher, learning contents and materials, experience of failure.

After collecting and calculating the obtained data, the present researcher found that Repetitive-Practice Technique was effective in teaching speaking ability. It can be seen from the result of descriptive statistics where the mean score and standard deviation of post-test were higher than pre-test.

From 5 interviewed students, the present researcher found that all of them do not like to speak English (demotivation) because they have some difficulties in English and they prefer to speak Arabic as daily communication in the area of islamic boarding school. 
Table 1

\begin{tabular}{c|c}
\multicolumn{2}{c}{ Number of Interviewees } \\
\hline No & $\begin{array}{c}\text { Students' initial } \\
\text { name }\end{array}$ \\
\hline 1 & MA \\
2 & H \\
3 & SH \\
4 & WHO \\
5 & ST \\
\hline
\end{tabular}

Table 2

\begin{tabular}{c|l}
\multicolumn{2}{c}{ Number of questions } \\
\hline No & \multicolumn{1}{c}{ Questions } \\
\hline 1 & $\begin{array}{l}\text { Do you like to use English as your daily } \\
\text { communication? }\end{array}$ \\
2 & $\begin{array}{l}\text { What makes it difficult for you to be } \\
\text { motivated to learn and speak English? }\end{array}$ \\
3 & $\begin{array}{l}\text { Do you believe that all the students of } \\
\text { EFL Learners are able to communicate } \\
\text { more using Arabic than English? }\end{array}$
\end{tabular}

As they answer the question "Do you like to use English as your daily communication?" Their answer are: MA:"I do not like to speak English because it is heavy for me to mention or pronounce its word. Also, there are so many English vocabulary that I do not master. What I get in the class sometimes different than what I learn outside". H: "I can speak English but I do not like to use it because I get difficulty to mention the English word. I have failed to memorize many vocabularies several years ago". SH: "I do not like to speak English because English word is difficult to be mentioned.Also, most of my friends just speak Arabic in the are of my Islamic Boarding School". WHO: "I do not like to speak English because of the teacher and for me English is more difficult than Arabic so I just speak Arabic". And the last is ST: "Actually I understand and I can speak English, but I do not like to use it because to pronounce it is difficult. Therefore, I prefer to speak Arabic.

After giving the questionnaire, the present researcher concludes that students get demotivation to use English as daily communication. As proved by the following result of questionnaire. 
Table 3

Questionnaire form

\begin{tabular}{l} 
Questions \\
\cline { 2 - 3 } \\
$\begin{array}{l}\text { I always discuss with my friends to } \\
\text { increase my ability in using English }\end{array}$
\end{tabular}

As what the present researcher found, the causes of students' demotivation are difficulties of English for EFL. While we have known that English as a Foreign Language refers to learning and using English as an additional language in a non-English speaking country.

Consequently, for people/students who do not speak English as their first language or called by English foreign learner might get difficulty in using English as daily communication as what the present researcher found in field of the study that all students who become sample get difficulties as well.

Based on the result of the interview, the present researcher found students' difficulty in mastering English vocabulary including spelling, idioms and slang of words because English has a usually large varied number of words or English has one of the biggest, trickiest vocabularies. In addition, other factors that demotivated students in speaking English were learning contents and material, the way their teacher taught and delivered the material and the 
influence of their failure in their past English learning experience. It became one of the reasons of the students' demotivation in using English as daily communication although they have a high motivation in learning English

As what answered by MA: "my difficulty in using English as my daily activity because I get difficulty in pronouncing some of English word, also there are so many of English daily vocabularies which I do not know and what I get in the class sometimes different than what I learn outside". It was answered also by WHO: "I do not like to speak English because of the teacher and their vocabularies are difficult to be mentioned". Also, clarified by SH: "I do not like to use English as my daily activity because I am lack of mastering English vocabularies and they are difficult to be mentioned".

Based on those statements above, it is known that the difficulties of English for EFL specifically difficulty in mastering English vocabularies including spelling, idioms and slang also the sheer number of words become the cause of students' demotivation in using English as daily communication in EFL Learners. Other factors that demotivated students in speaking English come from learning contents and material, the way their teacher taught and delivered the material and the influence of their failure in their past English learning experience.

In addition, Arabic environment is also the cause of students' demotivation in using English as daily communication. As what the present researcher stated above that EFL Learners was built in 2011. Since its first existence, it already applied Arabic as students' daily communication. It is also clarified by MA by answering a question "do you believe that all the students of EFL Learners are able to communicate more using Arabic than English?" MA: "yes, I do believe that all of the students are able to communicate it and we did it. Also, asserted by SH and three other interviewees who had similar answers to the question: "I am sure that all of the students of EFL Learners are able to use Arabic as daily communication. Moreover, in SMP Islam of EFL Learners has passed around 150 students which most of them continue their study to SMK Islam EFL Learners which is in one area with SMA Islam EFL Learners. Every day the students of these both institutions do association and communication.

Briefly, the students of SMK Islam influence them to communicate by using Arabic. As answered by all of samples by this question "why do not you like to use English as your daily communication" they cohesively answered "we do not like to speak English because most of our senior just speaks Arabic and we also prefer to speak Arabic than English. Based on the result of observation, interview and questionnaire, the present researcher found some solutions for students' demotivation to use English as their daily communication. As we know that the students' demotivation for the eighth graders of EFL Learners is caused by their difficulties of English, firstly in mastering English vocabulary including spelling, idioms and slang of words as well as the learning contents and material, English teacher and their failed English learning experience

Consequently, the teacher should put a big attention to this and teach the student maximal until the students get a proper ability as what it should because it becomes one of the 
reason of the students' demotivation in using English as daily communication although they have a high motivation in learning English and never afraid to make mistakes.

Specifically, the language teacher should be more careful in selecting appropriate teaching materials. Further, to reduce demotivation, teachers are suggested to pay more attention to the choice of teaching methods and their behavior that can increase students' motivation and interest in second language learning. Besides that, teachers should bear in mind that students have to be taught all language skills, including vocabulary and grammatical rules at the expense of oral skills. To make students motivated, teachers should be sensitive to the learning environments and individual experiences of students.

In addition, the leader of foundation of Islamic boarding school and also the teacher should make a regulation explicitly to divide a period of time for the student to speak English and also Arabic. So there will be a certain period of time to use both of those languages, for instance one month for English and one month for Arabic and also there will be an educated punishment for the students who do not go with the rule.

\section{CONCLUSION}

Based on the research finding, it shows that the students in EFL Learners. Have two causes of demotivation in speaking English which are: a) difficulties of English for EFL specifically coming from mastering English vocabularies including spelling, idioms and slang also the sheer number of words. In addition, the difficulty in understanding the learning contents and material, teachers' performance and their failed English learning experience were also the main factors and another determining factor is Arabic environment factor in which this Islamic Boarding school first existence already applied Arabic as students' daily communication. Consequently, Arabic has been rooting as students' daily communication from generation to generation and it is difficult to be changed.

While the solution for the students' demotivation are the language teacher should specifically be more careful in selecting appropriate teaching materials, pay more attention to the choice of teaching methods and their behaviour that can increase students' motivation and interest in second language learning and more to school's regulation which is made particularly for managing language in using English and Arabic as daily communication. Remember, there must be an explicit regulation including an educated punishment for everyone who does not obey the regulation.

\section{AUTHOR'S STATEMENT}

The author declares that this article has never been published in any journal.

\section{REFERENCES}

Amadi, S. C. (2018). Learning the English Passive Voice: Difficulties, learning strategies of Igbo ESL learners and pedagogical implications. International Journal of English and 
Literature, 9(5), 50-62.

Baugh, A., \& Cable, T. (1993). A history of the English language. Routledge.

Çankaya, P. (2018). Demotivation factors in foreign language learning. Journal of Foreign Language Education and Technology, 3(1), 1-17.

Clark, L., Pantidi, N., Cooney, O., Doyle, P., Garaialde, D., Edwards, J., Spillane, B., Gilmartin, E., Murad, C., \& Munteanu, C. (2019). What makes a good conversation? Challenges in designing truly conversational agents. Proceedings of the 2019 CHI Conference on Human Factors in Computing Systems, 1-12.

Freiermuth, M., \& Jarrell, D. (2006). Willingness to communicate: can online chat help? 1. International Journal of Applied Linguistics, 16(2), 189-212.

Gong, L., Liu, Y., \& Zhao, W. (2019). Dynamics of Emotional States and Their Relationship with Learning Outcomes during Learning Python with MOOC. Proceedings of the 2019 7th International Conference on Information and Education Technology, 71-76.

Han, J., \& Yin, H. (2016). Teacher motivation: Definition, research development and implications for teachers. Cogent Education, 3(1), 1217819.

Hartnett, M. (2016). The importance of motivation in online learning. In Motivation in online education (pp. 5-32). Springer.

Irwandi, I. (2020). Implementing Eclectic Method for ELT through Distance Learning during the Covid-19 Pandemic. Educatio, 15(2), 91-103.

Khouya, Y. B. (2018). Students Demotivating Factors in the EFL Classroom: The Case of Morocco. Advances in Language and Literary Studies, 9(2), 150-159.

Pitzer, J., \& Skinner, E. (2017). Predictors of changes in students' motivational resilience over the school year: The roles of teacher support, self-appraisals, and emotional reactivity. International Journal of Behavioral Development, 41(1), 15-29.

Song, B., \& Kim, T.-Y. (2016). Teacher (de) motivation from an Activity Theory perspective: Cases of two experienced EFL teachers in South Korea. System, 57, 134-145.

Song, B., \& Kim, T.-Y. (2017). The dynamics of demotivation and remotivation among Korean high school EFL students. System, 65, 90-103.

Subekti, A. S. (2018). An Exploration Of Learners'foreign Language Anxiety In The Indonesian University Context: Learners'and Teachers'voices. TEFLIN Journal, 29(2), 219-244.

Suparsa, I. N., Mantra, I. B. N., \& Widiastuti, I. (2017). Developing learning methods of Indonesian as a foreign language. International Journal of Social Sciences and Humanities (IJSSH), 1(2), 51-57. 